\title{
Are We Doing Our Homework? An Analysis of Food Engineering Education in Brazil
}

\author{
Vivian-Lara Silva ${ }^{a^{*}}$, Fausto Makishi ${ }^{\mathrm{b}}$, Marcus Magossi ${ }^{\mathrm{a}}$, Izabel Cristina Freitas \\ Moraes $^{a}$, Carmen Silvia Fávaro Trindade ${ }^{a}$, and Paulo José do Amaral Sobral ${ }^{a}$

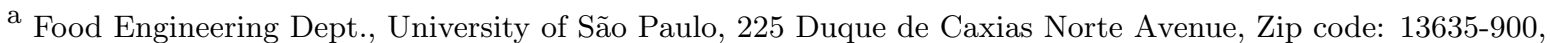 \\ Pirassununga (SP), Brazil \\ ${ }^{\mathrm{b}}$ Institute of Agricultural Sciences, Federal University of Minas Gerais, 1000 University Avenue, Zip code: \\ 39.404-547, Montes Claros (MG), Brazil \\ ${ }^{*}$ Corresponding author \\ vivianlara@usp.br \\ TEL FAX: $(+55$ 19) 35654284
}

Received: 2 November 2016; Published online: 18 October 2018

Invited paper from the 4th International ISEKI Food Conference - ISEKI Food 2016 - Bridging Training and Research for Industry and the Wider Community - Responsible Research and Innovation in the Food Value

\begin{abstract}
What is the profile of Food Engineering education in Brazil? Are we following the contemporary professional renewal trend? Driven by these questions, the present study analyzed data regarding 21 academic courses, which represent approximately $22 \%$ of the total bachelor's degree in food engineering courses offered in the country. Samples were defined considering a Brazilian annual ranking of undergraduate programs: very good (four stars) and excellent (five stars). Next, information was recovered from both the Brazilian Ministry of Education and institutional homepages of each analyzed program. The results suggest that food engineering programs exhibit relative identity, naturally due to their history and the path of each program and their faculty, shaping particularities in how fields of knowledge are constituted, in addition to their representativeness in the total workload of the program. However, initial analysis is suggestive regarding understanding that Brazil is not properly doing its homework, based on global movement, concerning food engineering education. The need to rethink Brazilian technical education, without culminating in additional workload, is emphasized, not only regarding new materials and technologies for learning and teaching, but also in terms of bringing a human and market approach. The achievement of this complex goal seems to be provided by the encouragement of student associations, transversal learning processes, and learning experiences outside the classroom as a means of improving undergraduate programs and human resources.
\end{abstract}

Keywords: Food science and technology; Engineering education; Curriculum development

\section{Introduction}

Over the past decades, Brazil has consolidated itself not only as a global food producer but also as an important consumer market in terms of industrialized goods. This context follows the recent development of the Brazilian manufacturing industry, in which the food industry plays a unique role. Part of this contemporary phenomenon reflects the growing demand for human resources in general, and engineers in particular (Batalha et al., 2005). In response to this context, an increasing amount of food engineering programs has been instituted across the country in the last decades. 
Currently, according to the Brazilian Ministry of Education, there are 96 undergraduate bachelor degree programs in this field in the country, equivalent to 7,000 admissions per year (MEC, 2016). It is important to state that Brazilian food engineering programs in the EU are equivalent to integrated masters courses (BSc+MSc) in Europe, being completed in five years, on average.

Therefore, the main purpose of the present study was to make observations regarding food engineering education in Brazil, emphasizing a particular issue: are we aligned with the effervescent discussion that occurs at the international level concerning future challenges of the career?

In this regard, the American Society for Engineering Education (ASEE) introduced a series of discussions through the "Advancing the Scholarship of Engineering Education: A Year of Dialogue", in order to ensure greater consistency between engineering education and current demands from society (Melsa, Rajala, \& Mohsen, 2009).

This initiative counted on the support of the North American industry, which was interested in promoting changes in the curricular and educational matrix, given the alignment of human resources with their particular needs. Similar movements were also observed in different parts of the world, such as Europe, Americas and Oceania (Alves, Restivo, \& da Silva, 2015; Borrego \& Bernhard, 2011).

It is interesting to note, however, that despite this, in the European Union, Flynn, Bejarano, Wahnstrom, Echim, and Quintas (2013) carried out a profile analysis of professionals in the field of Food Science and Technology in order to analyse why the sector exhibits low innovation rates when compared to other industries.

Flynn et al. (2013) suggested that the education of these professionals is on track. However, it has not yet reached sufficient amplitude or required depth in soft skills, which encompass abilities such as leadership, teamwork, and proactivity, as well as resilience and communication skills. Moreover, Saguy and Cohen (2016) highlight food engineering education should address entirely new topics and dimensions such as sustainability, economic environments, social responsibility, population growth, and aging. This is because a food engineering career is now confronted with unique challenges involving health, food security, and wellbeing (Silva, Sereno, \& do Amaral Sobral, 2018); and must play a proactive role in the ecosystem of innovation. At least in part, this movement comes from the most challenging moment that food engineering faces in the two centuries of history of the food industry (Aguilera, 2006). Indeeed, food engineers face increasingly complex challenges, such as a growing concern for health and wellness, development of functional foods, adapting nutritional profiles and foods for the elderly, high performance products for athletes, foods with lower calorie density, socioenvironmental performance, ethical food trades and production and so on (Besterfield-Sacre, Cox, Borrego, Beddoes, \& Zhu, 2014; Saguy \& Cohen, 2016). As a result, a multi and interdisciplinary approach is required (Saguy \& Cohen, 2016). Indeed, the need for scientific and technological development is intertwined with the social dynamics in which the food processing industry operates (Kasemodel, Makishi, Souza, \& Silva, 2016). Culminating in new, distinct and interrelated knowledge domains that must be approached in an articulated manner by food engineering education, such as biology, medicine, molecular gastronomy, new materials, and nanotechnology, in addition to concepts of market, and business economics (Saguy, Singh, Johnson, Fryer, \& Sastry, 2013).

An interesting highlight, however, is that while the topic of new routes of training in food engineering is increasingly discussed in different international forums around the world, in Brazil, the agenda remains unexplored and restricted to the specific context of undergraduate programs and their departments. With this in mind, the primary objective of the present study was to discuss if we are doing our homework in Brazil.

\section{Materials and Methods}

The curricula of 21 food engineering programs (approximately 22\% of those offered in Brazil) were analyzed. The sample was defined by considering the 2016 Brazilian Student Guide ("Guia do Estudante 2016"), a traditional annual assess- 
An analysis of food engineering education in Brazil $\mid 3$

ment of undergraduate programs in the country. This annual report contains the evaluation results of programs classified in stars: good (three stars), very good (four stars), and excellent (five stars). The evaluation system consists of an annual collection of qualitative and quantitative data per program, in electronic format, of a commission formed by at least seven experts (referees), including course coordinators, department directors, and professors. The analyzed criteria gather information on faculty, didacticpedagogical projects, scientific production, extension activities, internationalization, insertion of students in the job market, infrastructure, and supply of postgraduate courses. Each of the seven referees awarded grades according to criteria: excellent (5), very good (4), good (3), regular (2), poor (1) and "I'd rather omit myself"; in which case a new assessor is invited to participate. The top and bottom scores were disregarded to eliminate distortion. The mean was calculated from five assigned scores. The final grade was calculated from the weighted average of the grades obtained in the last three years. Programs receiving scores between 4.3161 and 5 were classified as five stars, and those receiving scores between 3.6322 and 4.3161 (Guia do Estudante, 2016).

For the 2016 Brazilian Student Guide, the analysis was performed using programs certified as five stars ( a total of 5 programs) and four stars (a group of 16 programs). Once selected, undergraduate program information was recovered from the official databases of the Brazilian Ministry of Education (MEC, 2016), as well as from the institutional homepages of each program. The following data were collected: 1. year of establishment; 2. location; 3. annual number of admissions; 4 . required and elective courses; 5 . credit hours per course, and 6. total workload. Required and elective courses were divided into groups, representing their particular field of knowledge, totaling nine groups: 1. Basic Sciences; 2. Engineering Sciences; 3. Food Sciences; 4. Human Sciences; 5. Technologies; 6. Supervised Internship; 7. Monograph; 8. Elective Courses, and 9. Learning Experiences Outside the Classroom. The proposed division was based on the model and taxonomy utilized by the University of São Paulo (USP).
Table 1 summarizes the criteria applied for the proposed division. The data collection process covered the period from 15 to 25 December, 2015. Data were grouped into a spreadsheet in Excel format, which formed the basis for further analysis and discussion.

Additionally, in order to analyze the role of learning experiences outside the classroom (not included in the educational plan), an assessment of student associations linked to food engineering programs was carried out. These associations are organizations that are formed exclusively by undergraduate students who represent the students' interests, and which retain civic, cultural, educational, sporting, business, and social purposes.

The following student associations were considered: 1) AIESEC (originally a French acronym for Association Internationale des Etudiants en Sciences Economiques et Commerciales; dedicated to empowering young people for peace and fulfillment of mankind's potential); 2) Athletic Associations; 3) Enactus (whose name comes from the combination of three words: Entrepreneurial, Act, and Us; representing a community of student, academic, and business leaders committed to using the power of entrepreneurial action to transform lives and shape a better, and more sustainable world); 4) Junior Companies and 5) Program of Tutorial Education (PTE).

The selection of this set of five student associations was deliberate. Athletic Associations, Junior Companies, and PTE are a few of the leading traditional and disseminated student organizations in Brazil. In turn, AIESEC and Enactus emerge as distinctive international student associations around the world. These student associations have been identified as strategic organsiations for learning outside the classroom through interdisciplinary exposure to the real-world problems (Gair, 1997; Dillon et al., 2006; Paisley, Furman, Sibthorp, \& Gookin, 2008). 
Table 1: Characterization of areas of knowledge: Main content and course examples

\begin{tabular}{|c|c|c|}
\hline KNOWLEDGE GROUPS & MAIN CONTENT & $\begin{array}{l}\text { COURSES } \\
\text { EXAMPLES }\end{array}$ \\
\hline Basic Sciences & $\begin{array}{l}\text { Related to basis of engineering knowledge and } \\
\text { that are used as tools for other courses throughout the program. } \\
\text { These courses are common to all engineering programs. }\end{array}$ & $\begin{array}{l}\text { Calculus, Physics, } \\
\text { and Statistics }\end{array}$ \\
\hline Engineering Sciences & $\begin{array}{l}\text { Linked with chemical } \\
\text { and food processing. }\end{array}$ & $\begin{array}{l}\text { Transport Phenomena, } \\
\text { Unit Operations, and } \\
\text { Biochemical Engineering }\end{array}$ \\
\hline Food Sciences & $\begin{array}{l}\text { Courses that study the reactions, } \\
\text { composition, and analysis of food. }\end{array}$ & $\begin{array}{l}\text { Food Biochemistry, } \\
\text { Food Analysis, and } \\
\text { Food Microbiology }\end{array}$ \\
\hline Human Sciences & $\begin{array}{l}\text { Related to humanities } \\
\text { and social sciences. }\end{array}$ & $\begin{array}{l}\text { Sociology, Economy, and } \\
\text { Food Distribution }\end{array}$ \\
\hline Technological Processes & $\begin{array}{l}\text { Linked with the study of food processing, } \\
\text { in terms of specific methods or } \\
\text { technological packaging. }\end{array}$ & $\begin{array}{l}\text { Processing of Meat and Derivatives, } \\
\text { Milk Technology, } \\
\text { and Packaging Technology }\end{array}$ \\
\hline Monograph & $\begin{array}{l}\text { Related to the concluding } \\
\text { course assignment. }\end{array}$ & Final Project \\
\hline Supervised Internship & $\begin{array}{c}\text { Related to the } \\
\text { supervised internship. }\end{array}$ & Training Program \\
\hline $\begin{array}{l}\text { Elective } \\
\text { Courses }\end{array}$ & $\begin{array}{l}\text { Free courses chosen by the student } \\
\text { (having to attend a minimum amount of credits). }\end{array}$ & $\begin{array}{l}\text { Excel, Autocad, Emerging Technologies } \\
\text { for Food Processing, Eco-Design }\end{array}$ \\
\hline $\begin{array}{l}\text { Learning Experiences } \\
\text { Outside the Classroom }\end{array}$ & $\begin{array}{l}\text { Linked with culture and extension activities } \\
\text { (with a maximum amount of hours to benefit). }\end{array}$ & $\begin{array}{c}\text { Technical visits, } \\
\text { Participation in } \\
\text { Student Associations, } \\
\text { Attendance in Workshops and Conferences. }\end{array}$ \\
\hline
\end{tabular}

Source: The authors, based on information available on the websites of the analyzed food engineering programs

\section{Results and Discussions}

\subsection{Food engineering: professionals to relieve world hunger and more}

Before presenting the results obtained in this study, we will present an overview of food engineering in the world and in the Brazil.

The search for a better-aligned preservation for safe and healthy foods drives the development of this sector and its profession. Although each country seems to have developed its own identitity in structuring food engineering as a profession and a career, Karel (1997) identified two primary branches at the origin of contemporary food engineering education: 1) food engineering, which originated as an agricultural engineering specialization; and 2) food science and technology, which is mainly associated with chemistry but also incorporates elements of microbiology and agronomy. The first is related to the European school, more specifically the French one, while the second refers to the American or AngloSaxon school (Kostaropoulos, 2012).

Indeed, in some European countries, such as France, food engineering is a derivation of agricultural engineering, l'Ingénieur Agroalimentaire, and emphasis should be given to the formation of l'École Nationale des Industries Agricoles (ENSIA), which occurred in 1893 (Agroparistech, 2018). Starting from that and benefiting from the European industrial revolution that occurred in the early 1900s, food engineering was strongly associated with small-scale agroindustrial production (nearly one century before the emergence of food engineering in the USA), which began to supply the growing European working class (Abramovay, 1992). Preservation techniques, such as appertization and pasteurization, date back to the same period.

On the other hand, in the USA, food engineering developed differently and was initially introduced as Food Technology, consolidating itself as a career in the early 1920s and having matured recently in the academic field (Kostaropoulos, 
2012; Saguy et al., 2013). The profession emphasizes the industrialization process and the competitiveness of the segment, particularly in gaining scale. In other words, the American Food Engineering School was developed amidst the green revolution, based on large-scale rural and industrial production, retaining a high degree of automation and increasing productivity. In this context, Loncin (2012) described food engineering as an adaptation of techniques from chemical engineering, focusing on the food industry.

Besides these two branches discussed by Karel (1997), Kostaropoulos (2012) described a third branch concerning the origin of contemporary food engineering, which originated from the combination of mechanical and chemical process engineering in Germany. In that view, Kupriano (Kostaropoulos, 2012) emphasized that the Technical University of Karlsruhe launched its first food engineering program, denominated Food Techniques, in 1948. In Germany, agricultural development was followed by strong industrial advancement in the mechanical and chemical fields. This path led to a direct unfolding in German food engineering programs, which are distinguished by knowledge production in the field of projects and industrial process dimensioning (Costa, Mozina, \& Pittia, 2014). The program was primarily structured as a field of chemical engineering, particularly associated with food science, food chemistry, physical chemistry, and, on a smaller scale, biology and microbiology (Kostaropoulos, 2012).

In summary, the three previously described schools (European, American and Germany) contributed considerably to the contemporary understanding of food engineering. Evidently, the distinction among them is much less sensitive in the current global context in which similarities and differences between curricula occur and in which new and more complex challenges seem to be placed on this profession.

As observed by Barbosa-Canovas and Ibarz (2002), food process engineering aims to study the principals and laws that govern the physical, chemical, or biochemical stages of distinct processes, as well as the apparatus or equipment by which such stages are industrially carried out. It incorporates food engineering principles, such as essential elements of food process- ing, transformation, preservation, material sciences, food equipment, and plant design to deal with operations of whole food processing units, including storage and logistics, instrumentation and automatic control, and feasibility studies (Kostaropoulos, 2012).

But this seems to be only part of the training currently required of the food engineer. With the increasing demand for products that meet the specific needs of particular consumer groups, the food engineer's education is undergoing a time of review. The future seems to cover professional responsibility for operationalizing the efforts conducted so far in food science and technology, while respecting the constraints of economic viability, social impact, and environmental conservation (Karel, 1997; Saguy et al., 2013; Silva et al., 2018).

This discussion is globally underway in different food engineering programs and, of course, it is still necessary to adjust to the local context. Indeed, although food production and distribution occur at a global level, each country seems to have developed its own identitity in structuring food engineering as a profession and a career. In particular, the present study aims to assess how the topic is perceived in Brazil, as discussed in the following section.

\subsection{Food engineering in Brazil}

With a delay, relative to the development of the sector in Europe and the USA, the history of food engineering in Brazil only began to develop properly in the late 1960s, early 1970s.

This time marks a beginning to the development of the food industry in Latin America. The industrial sector as a whole was incipient in these countries, including Brazil, in which the exportation of commodities was the primary economic activity (Bulmer-Thomas, 2003; Skidmore, 2009). Particularly within the Brazilian context, the industrial process was encouraged and stimulated by the government, which predominantly focused on the steel and transportation industries. The Brazilian food industry in turn developed during this period, absorbing external technologies, such as UHT milk processing (a memorable example of the role of a food en- 
$6 \mid$ Silva et al.

gineering career and the offer of products with low cost, and extended shelf life, versus longer distribution routes). Moreover, the oil crisis and increase in prices led to a concern regarding food production. It was exactly in this period that the first engineering programs were founded in Brazil.

However, the awakening of Brazil to food engineering training would pass through another moment of numbness. This was due to another economic crisis that paralyzed Brazilian industrial development and impacted negatively on industrial food processing. More specifically, the 1980s were considered a lost decade, in which economic and political uncertainty prevailed in different Latin American countries, including Brazil.

In turn, in the 1990s, economic stabilization, market deregulation, and trade liberalization led to a new impulse for the Brazilian food industry. And so, from the second half of the 1990s, the country consolidated itself as a global food producer, becoming one of the leading agricultural product suppliers in the new millennium. The development of the Brazilian consumer market awakened the interest of many multinational food companies, significantly increasing the job supply in the sector.

Following this story, the origin of Brazilian food engineering was related to the creation of ITAL (Food Technology Institute) in 1962, resulting from the dismemberment of a section of the IAC (Agronomic Institute of Campinas, situated in the State of São Paulo). A few years later, in 1967, the first food engineering School was instituted by UNICAMP (State University of Campinas), followed by UFV (Federal University of Viçosa) in 1975, UFPB (Federal University of Paraíba) and UFC (Federal University of Ceará) in 1976, and UFSC (Federal University of Santa Catarina) and FURG (Federal University of Rio Grande) in 1979.

Afterward, as illustrated in Table 2, the program was introduced to UNIFEB (Educational Foundation of Barretos) in 1980, UNESP (São Paulo State University) in 1983, FENVA (Engineering College of Varginha) in 1984, Maua Engineering School in 1986, UNIMEP (Metodista de Piracicaba) in 1988, and PUC/PR (Pontifical Catholic University of Paraná) in 1989. São Paulo University (USP) inaugurated its course in 2001.
The UNICAMP program was structured by a multidisciplinary team of professors from the fields of mechanical, agronomic, agricultural, and chemical engineering, as well as mathematics and biology, having as its main reference the American school, as discussed in the previous section. More specifically, the influence came from the Food Science and Technology curriculum of the University of California. In turn, at UFV, the program evolved from the Food Technology specialization offered in the Agronomy program; while at UFPB, the food engineering program was associated with the Department of Chemical and Food Technology.

In addition to the mechanical, agronomic, agricultural and chemical engineering programs, other fields of knowledge are also verified in the genesis of other food engineering programs currently active in Brazil (MEC, 2016), such as production engineering, animal science, economy and business. From its establishment, food engineering programs have been implemented in various colleges and universities in several regions of the country. Figure 1 shows their distribution in Brazil.

But it is precisely from the end of 1990s that training in food engineering reached its boom in Brazil. Regarding the previous discussion, Figure 2 outlines the relatively recent dissemination of food engineering programs in Brazil, with respect to the number of students entering the programs, which has become more pronounced over the past 15 years, when approximately $70 \%$ of the existing courses were instituted. This period corresponds to the increasing stability of the Brazilian economy, inferring an attractive economic context to the growing mass of food engineers provided annually by schools since then.

As illustrated in Figure 1, there is a greater concentration of food engineering programs in the South and Southeast regions of Brazil, highlighting São Paulo and Minas Gerais states that together account for $36 \%$ of all programs offered. The mentioned states are known for retaining some of the largest centers of consumption in the country, and the highest concentration of large food processing industries.

However, another result should not be overshadowed. The progression of food engineering programs towards the countryside (Figure 1) sug- 
An analysis of food engineering education in Brazil $\mid 7$

Table 2: Top 21 Brazilian food engineering programs: Characterization by year of course establishment, location, and the number of students enrolled annually

\begin{tabular}{lccc}
\hline \multicolumn{1}{c}{ Program } & $\begin{array}{c}\text { Year of course } \\
\text { establishment }\end{array}$ & $\begin{array}{c}\text { Location } \\
\text { (City/State) }\end{array}$ & $\begin{array}{c}\text { Number of students } \\
\text { enrolled annually }\end{array}$ \\
\hline UNICAMP - Universidade Estadual de Campinas & 1967 & Campinas-SP & 115 \\
UFV - Universidade Federal de Viçosa & 1975 & Viçosa-MG & 60 \\
UFC - Universidade Federal do Ceará & 1976 & Fortaleza-CE & 100 \\
UFPB - Universidade Federal da Paraíba & 1976 & João Pessoa-PB & 30 \\
FURG - Universidade Federal do Rio Grande & 1979 & Rio Grande-RS & 50 \\
UFSC - Universidade Federal de Santa Catarina & 1979 & Florianópolis-SC & 50 \\
UNIFEB - Fundação Educacional de Barretos & 1980 & Barretos-SP & 40 \\
UNESP - Universidade Estadual Paulista & 1983 & S. J. do & 30 \\
FENVA - Faculdade de Engenharia de Varginha & 1984 & Rio Preto-SP & 30 \\
Instituto Mauá & 1986 & Varginha-MG C. do Sul-SP & 40 \\
UNIMEP - Metodista de Piracicaba & 1988 & Piracicaba-SP & 60 \\
PUC/PR - Pontifícia Universidade Católica do Paraná & 1989 & Curitiba-PR & 60 \\
UFRRJ - Universidade Federal Rural & 1991 & Seropédica-RJ & 60 \\
do Rio de Janeiro & 1992 & São Leopoldo-RS & 90 \\
UNISINOS - Universidade do Vale do Rio dos Sinos & 1995 & Porto Alegre-RS & 30 \\
UFRGS - Universidade Federal do & 1998 & Passo Fundo-RS & NF \\
Rio Grande do Sul & 1999 & Goiânia-GO & 60 \\
UPF - Universidade de Passo Fundo & 1999 & Itapetinga-BA & 40 \\
UFG - Universidade Federal de Goiás & 2000 & Belém-PA & 32 \\
UESB - Universidade Estadual do & 2000 & Maringá-PR & 40 \\
Sudoeste da Bahia & 2001 & Pirassununga-SP & 100 \\
UFPa - Universidade Federal do Pará & 2001 & Caxias do Sul-RS & 50 \\
UEM - Universidade Estadual de Maringá & 2001 & São Cristovão-SE & 50 \\
USP - Universidade de São Paulo & 2003 & Lavras-MG & 100 \\
UCS - Universidade de Caxias do Sul & 2004 & Rio de Janeiro-RJ & 40 \\
UFS - Universidade Federal de Sergipe & 2007 & Rio Verde-GO & 50 \\
UFLA - Universidade Federal de Lavras & & & \\
UFRJ - Universidade Federal do Rio de Janeiro & & \\
IFGoiano - Instituto Federal Goiano & & & \\
\hline & & & \\
\end{tabular}

Note: NF (Information not found). Source: The authors, based on information obtained from the Brazilian Ministry of Education (MEC, 2016)

gests an open issue: the impact on the standard curricula regarding topics of regional or local interest, such as Amazon and Cerrado fruit processing, reductions in water use, and technologies to generate income in vulnerable populations.

\subsection{Total Workload}

The total workload of the 21 courses analyzed presents a standard deviation of 300 hours more or less, which suggests a quantitative difference between courses. Reviewed courses rated as five stars have a leaner workload compared to most of the courses rated four stars.

Figure 3 illustrates the total workload in hours of each of the 21 programs analyzed in the present study. The light gray bars represent programs certified as four stars by the 2016 Brazilian Student Guide (Guia do Estudante, 2016), while the dark gray bars characterize programs that were considered as five stars by the same ranking. In general, the programs rated as five stars exhibit reduced workload when compared to those rated as four stars.

In the international context, some authors suggested reduction of hours in the classroom could encourage students to pursue different activities such as voluntary work, practice in laboratories or in industry (following internship programs), as well as the development of research projects (introduction to science research) or even expe- 
$8 \mid$ Silva et al.

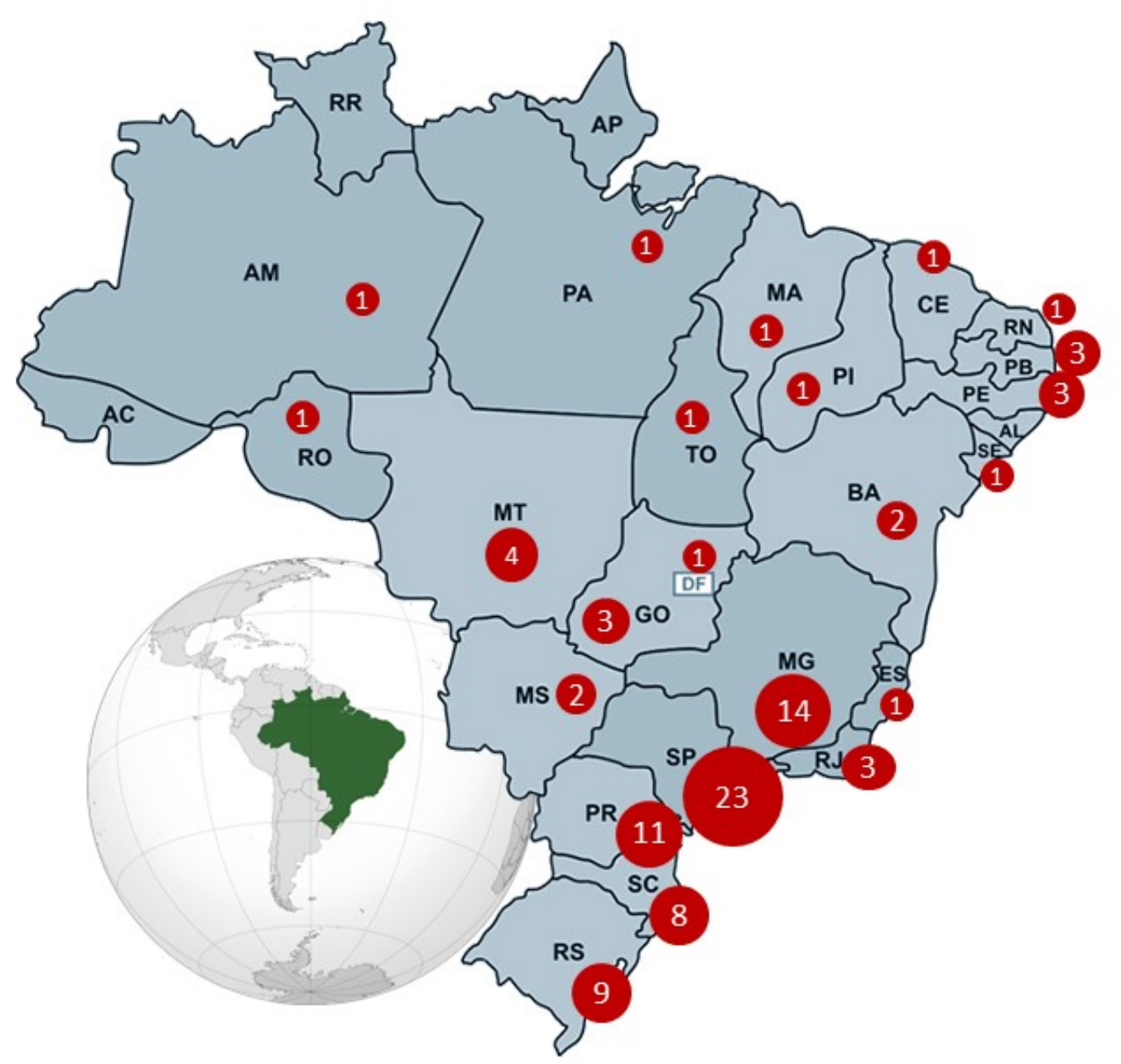

Figure 1: Distribution of the 96 food engineering programs in Brazil. Source: The authors, based on information obtained from the Brazilian Ministry of Education (MEC, 2016) 
An analysis of food engineering education in Brazil $\mid 9$

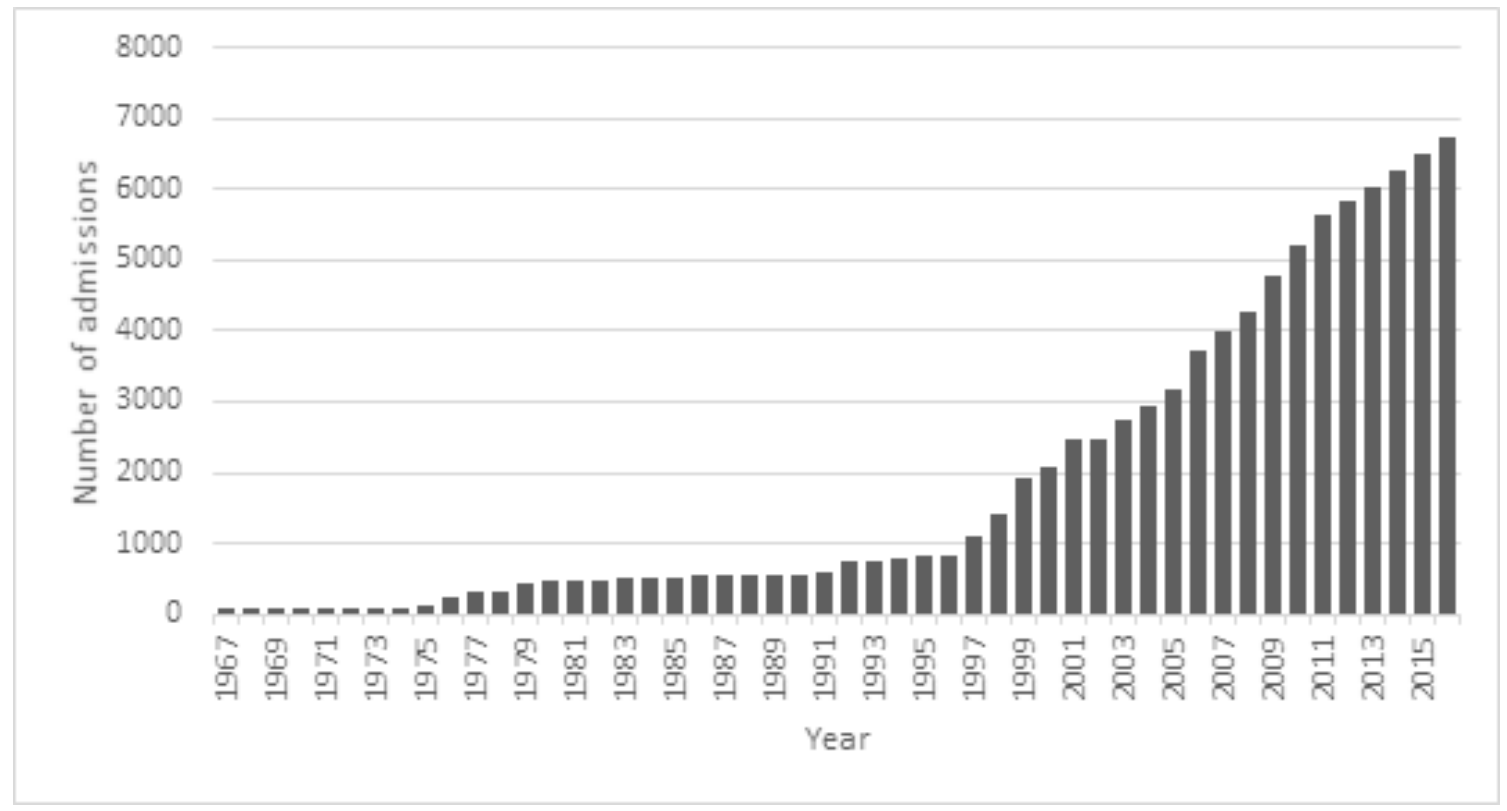

Figure 2: Number of admissions per year since the implementation of food engineering education in Brazil. Source: The authors, based on information available on the websites of the analyzed programs

rience abroad (in university exchange programs). This in turn allows the enhancement of new and complementary content (Flynn et al., 2013; Saguy et al., 2013; Saguy \& Cohen, 2016). On the other hand, it is difficult to say if students willprefer more free time. Finding the incentive and monitoring mechanisms for complementary training in engineering courses are challenges. Any way, in Brazil, some of the courses analysed have incorporated hours dedicated to activities outside the classroom as mandatory requirements of their programs. This is the case of UFRRJ, FURG, UESB, UFRGS and Unisinos, which account for an average of 180 hours as experiences outside the classroom. In other courses, students' participation in these activities is voluntary.

Regardless of the quantitative aspect of the global workload of the programs in question, with respect to the qualitative analysis, Brazilian curricula display a particularly proportional pattern regarding 'fields of knowledge'. This statement was derived from a complementary assessment that refers to an in-depth qualitative analysis of the 21 programs analyzed in the present study.
This is shown in detail in the next section.

\subsection{Fields of Knowledge Analysis}

A comparative analysis of the curriculum of very good (four stars) and excellent (five stars) food engineering programs in Brazil is shown in Figure 4. In spite of other classifications of possible courses, the present study proposed a set of knowledge groups, considering the Brazillian curriculum, as follows: 1. Basic Sciences; 2. Engineering Sciences; 3. Food Sciences; 4. Human Sciences; 5. Technological Processes; 6. Supervised Internship; 7. Monograph; 8. Elective Courses, and 9. Learning Experiences Outside the Classroom.

In general, Basic Sciences, Engineering Sciences, Food Sciences, Human Sciences, Supervised Internship, Monograph and Elective Courses have similar workloads considering the 21 studied curricula, disabling the visualization of significant differences between the programs classified as very good and excellent. A point of difference between the two groups concerns the workload attributed to Technology disciplines and Learning 


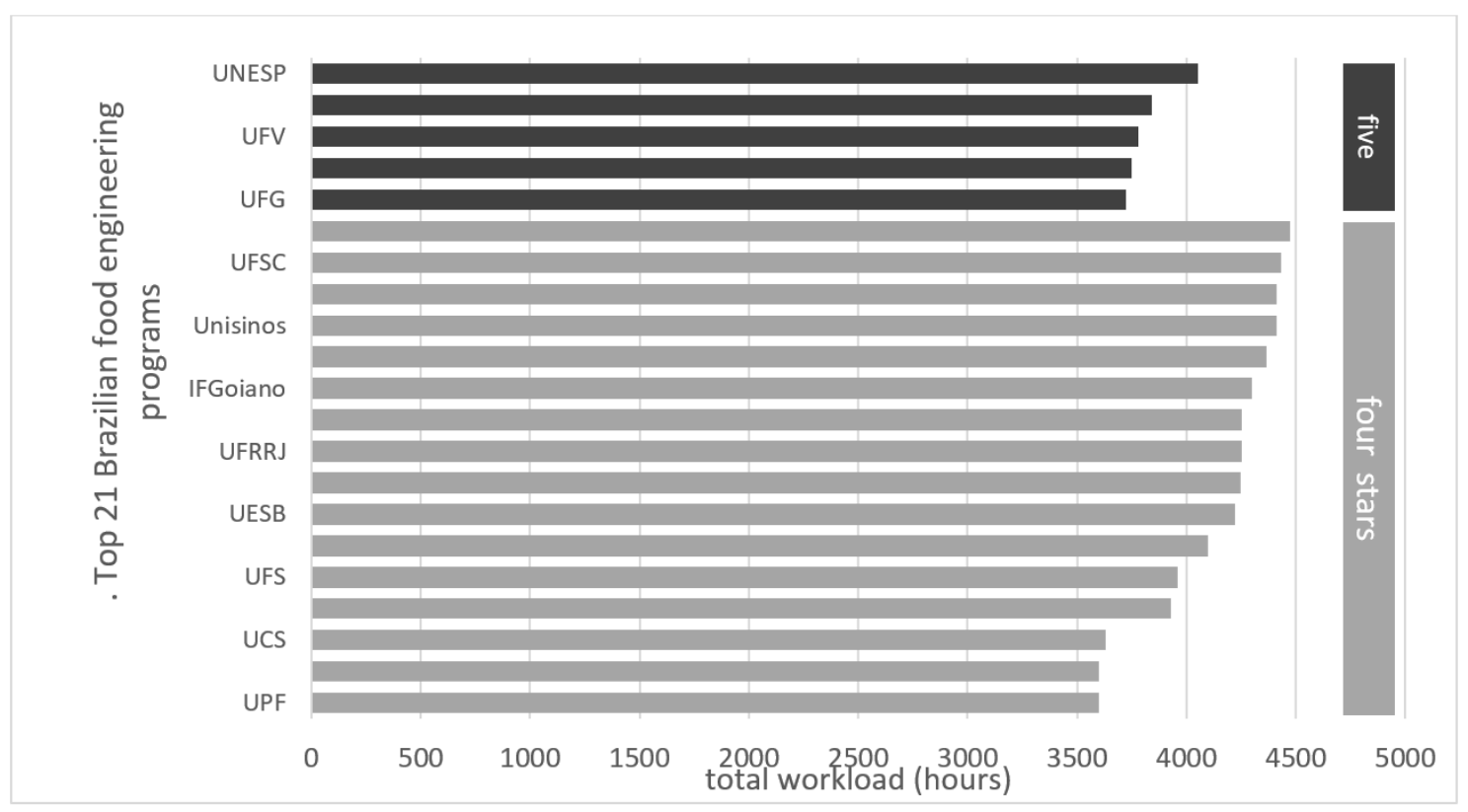

Figure 3: Top 21 Brazilian food engineering programs (four and five stars): characterization by total workload in hours. Source: The authors, based on both the Brazilian Ministry of Education ((MEC, 2016) and information available on the websites of the analyzed programs. Note: The Brazilian Government sets a minimum of 3,600 hours for food engineering education (distributed in 5 years)

Experiences Outside the Classroom. Programs classified as excellent have higher workloads in Food Technology disciplines and lower ones in Learning Experiences Outside the Classroom. It is noteworthy that the infrastructure, generally associated with the disciplines provided by the Technological processes group, such as laboratories and pilot processing units, are attributes evaluated by the Brazilian ranking. Including substantial financial investments, the incorporation of this type of discipline in the curriculum can be difficult for some programs, thus considered an obstacle in curriculum development.

The disaggregated analysis of the Top 5 programs (five stars), in the nine areas of knowledge, assists in understanding the heterogeneity of the Brazilian food engineering programs (Figure 5). The programs developed at the University of São Paulo (USP) and the Federal University of Goiás (UFG) proportionally exhibit more hours dedicated to core disciplines. The State University of Campinas (UNICAMP) and the Federal Uni- versity of Viçosa (UFV) display smaller representations of these disciplines, with greater importance for technological processes such as meat, grain, fish and fruit processing and baking.

Basic Sciences represent $34.5 \%$ of the average workload of the 21 analyzed programs. Furthermore, it is noteworthy that the UFG and USP programs exhibit values well above average, accounting for $39.9 \%$ and $39.7 \%$, respectively. This result indicates a considerable concern for the solid formation of basic or initial concepts, in addition to providing a foundation for an improved learning experience of supplementary fields encountered by the student. Part of the discussion takes place at international debates (Besterfield-Sacre et al., 2014; Roos et al., 2016; Saguy \& Cohen, 2016), which have argued that the solution to increasingly complex problems is the deepening of basic sciences, such as mathematics, statistics, 


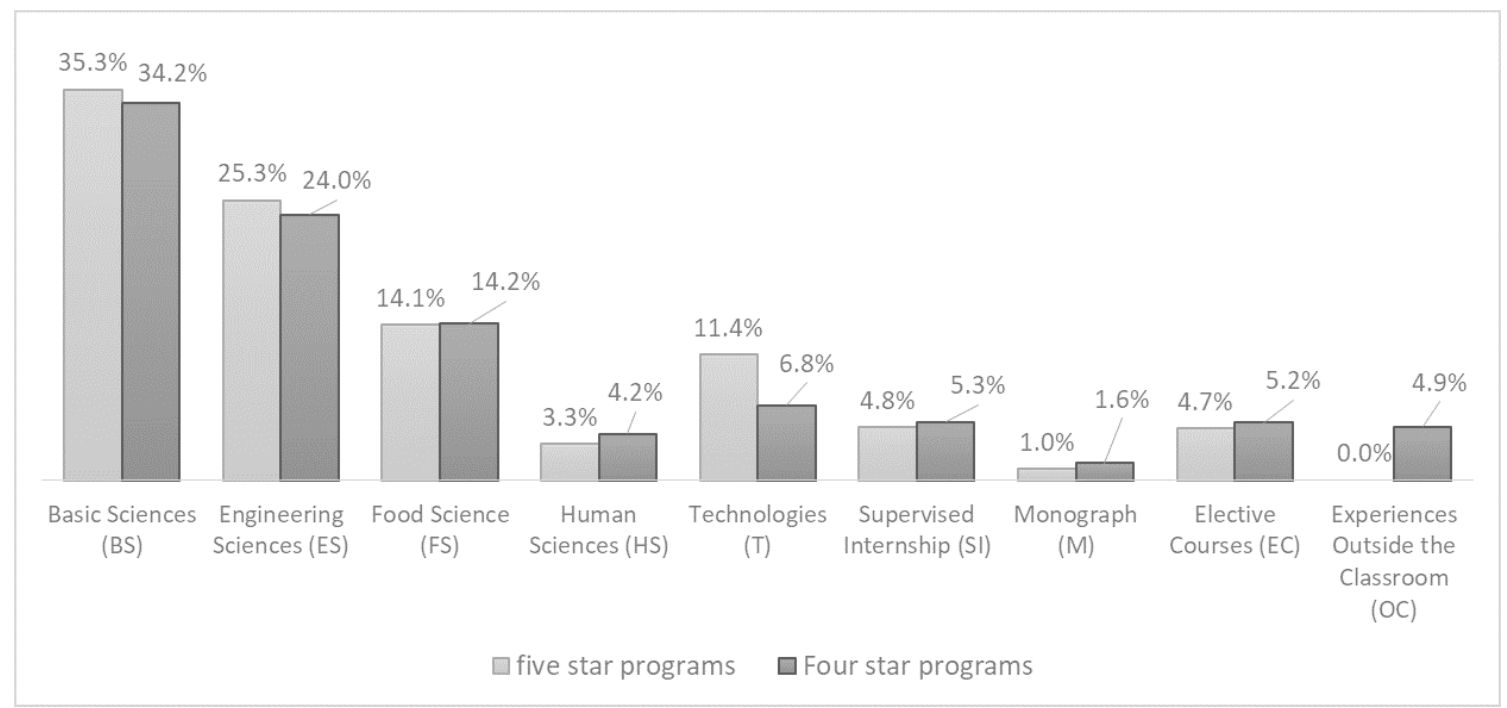

Figure 4: Comparative analysis of the Engineering program curriculum: very good (four stars) and excellent (five stars), considering nine fields of knowledge. Source: The authors, based on information available on the websites of the analyzed programs

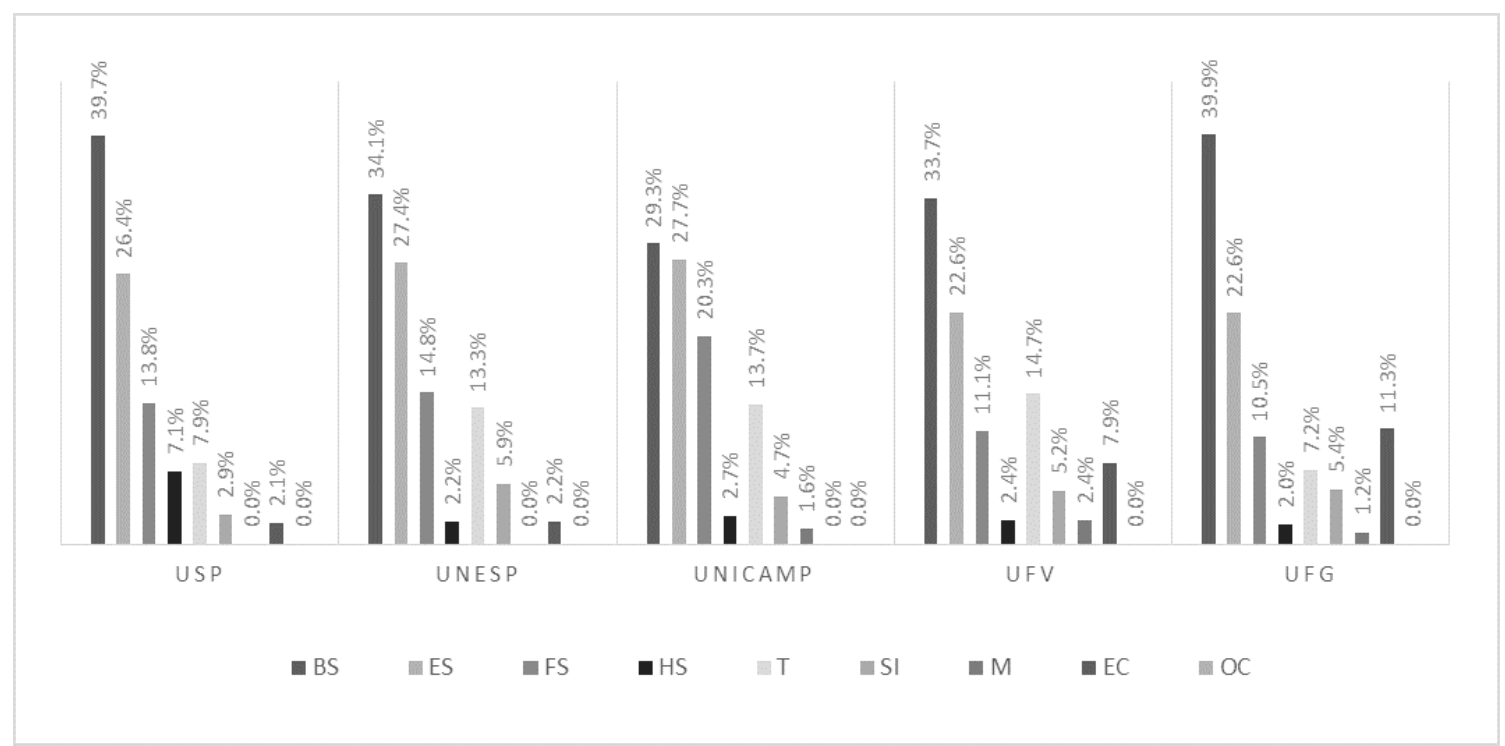

Figure 5: Individualized analysis of the top 5 engineering programs in Brazil according to area of knowledge: Basic Sciences (BS); Engineering Sciences (ES); Food Sciences (FS); Human Sciences (HS); Technological Processes (T); Supervised Internship (SI); Monograph (M); Elective Courses (EC), and Learning Experiences Outside the Classroom (OC). Source: The authors, based on information available on the websites of the analyzed programs 
physics, chemistry, and biology.

Engineering Sciences represent $24.3 \%$ of the average workload of the 21 analyzed programs. Moreover, as shown in Figure 5, this field of knowledge displayed a higher percentage in programs rated as five stars than in the combined averages of programs rated as five and four stars. No significant discrepancy was verified between the values corresponding to each food engineering program. This result indicates certain homogeneity between the total workload regarding this knowledge group for all of the food engineering programs analyzed, indicating that this factor exhibits similar importance in all programs.

Food Sciences represent $14.2 \%$ of the average workload of the 21 programs analyzed. The combined averages of the programs reveal similar percentages. However, it is noteworthy that UNICAMP showed a value of $20.3 \%$, which is superior to the mean of the 21 programs $(14.2 \%)$, as well as the average of the programs rated as five stars (14.1\%).

Human Sciences represent $4 \%$ of the average workload of the 21 analyzed programs. Programs rated as five stars exhibited a lower percentage when compared to the combined averages of the programs rated as four and five stars. In addition, emphasis should be given to the USP program, which displayed a $7.1 \%$ average regarding this knowledge group, superior to the mean of the 21 programs $(4 \%)$.

Technological processes represent $7.9 \%$ of the average workload with respect to the 21 programs analyzed. This field of knowledge displayed a higher percentage in programs rated as five stars than in the combined averages of the programs rated as four and five stars. Moreover, it is relevant to note that UNESP, UNICAMP, and UFV exhibited superior values when compared to the mean of the programs rated as five stars, as well as the combined averages of the programs rated as four and five stars.

In turn, the consolidation of the concepts regarding classroom knowledge, as well as familiarizing students with operational and managerial routines, occurs mainly by way of a mandatory Supervised Internship. As observed by Roos et al. (2016) and Flynn et al. (2013), the approach of academia and industry proves to be a determining factor in the professional training of the engineer. In the present study, approximately $5 \%$ of the workload was devoted to compulsory internship activities, such as a training program, regarding the average workload of the 21 analyzed programs. Moreover, in most of the courses, students are encouraged to develop additional hours in this type of experience.

Monograph represents $1.4 \%$ of the average workload of the 21 analyzed programs. A relevant discrepancy was observed between each food engineering program and the average of the programs rated as five stars, as well as the combined averages of programs rated as four and five stars. This occurs because some food engineering programs do not require the integration of a final project in their curricula.

Elective Courses represent $4.9 \%$ of the average workload of the 21 analyzed programs. This percentage refers to the minimum quantity of credits that must be completed in each program. Additionally, a small discrepancy between the average of the programs rated as five starts and the combined averages of the programs rated as four and five stars was verified. However, a relevant variation was observed among the programs rated as five stars.

Lastly, it is relevant to note that Experiences Outside the Classroom are not recog- 
An analysis of food engineering education in Brazil $\mid 13$

nized as workloads in the programs rated as five stars (USP, UNESP, UNICAMP, UFV, and UFG). In contrast, programs rated as four stars offer courses regarding this field of knowledge. It is worth noting that the programs rated as five stars do not include experiences outside the classroom in their workloads since they are deemed voluntary.

After considering the workloads of the top 21 Brazilian food engineering programs, it would be interesting to discuss how the reduction in workload can contribute to promote and/or improve the out-of-class activities, contributing to complementary education, including certain soft skills. In this regard, several authors have suggested that the involvement in activities outside the classroom in real-world problems allow acquired knowledge to be added to other skills, forming essential skills for future professionals (Dillon et al., 2006; Paisley et al., 2008). While, in the European Union, professionals are required to gain soft skills (Flynn et al., 2013), in Brazil this is not different. However, these characteristics are often difficult to develop in the classic teaching-learning models.

\subsection{Student Associations and Soft Skills}

The Programme for International Student Assessment (PISA) defines as a key competency the ability to successfully meet complex demands in a particular context. Competent performance or effective action implies the mobilization of knowledge and cognitive and practical skills, as well as social and behavioral components, such as attitudes, emotions, and values and motivations (Rychen \& Salganik, 2003).

However, if such skills are valued and furthermore necessary, how can they be developed in the academic environment? Additionally, how can such attributes be incorporated into academic education?

An initial insight was obtained from data shown in Table 3, which indicate the presence or absence of student associations in food engineering programs.
Many authors have suggested that the participation in student organizations is an essential method for the development of key competencies (Eccles \& Barber, 1999; Knight, 2004; Berman \& Ritchie, 2006; Lucena, Downey, Jesiek, \& Elber, 2008).

Aligned to that approach, to integrate student associations provide a way of developing soft skills that are usually not fully developed throughout undergraduate programs. These initiatives allow students to implement competencies such as leadership, teamwork, proactivity, resilience, and communication skills, among others, which will be demanded of them when they enter the job market.

The foundation of these pedagogical tools is supported by a problem-based learning approach, which proposes the students' exposure to sufficient situations in order to enable them to seek knowledge for themselves when faced with a problem (Wood, 2003).

The learning experiences outside the classroom represent the main incentive that food engineering programs in Brazil provide in order to meet the market demand for complete professionals, whether in soft or hard skills, whohave the professional knowledge, tools, and techniques to be qualified for the career in question.

Nevertheless according to the evidence in Table 3 , there is still a long path to follow in food engineering education, not only in implementing initiatives in all of the programs but also in disseminating them among the entire student population.

\section{Conclusion}

The present study developed a critical analysis of food engineering education in Brazil, and its results suggest that the Brazilian programs retain similar curricular structures, although variations were observed. In addition to the curricula, incentives provided by food engineering programs to student associations were described, culminating in a learning experience of abilities that are commonly referred to as soft skills. The results also suggest that these programs exhibit relative identity, naturally due to their history and the path of each program and their faculty, shaping 
Table 3: Active student associations in each food engineering program

\begin{tabular}{|c|c|c|c|c|c|}
\hline Program & $\begin{array}{l}\text { Program of Tutorial } \\
\text { Education }\end{array}$ & Enactus & $\begin{array}{l}\text { Junior } \\
\text { Company }\end{array}$ & AIESEC & $\begin{array}{c}\text { Athletic } \\
\text { Association }\end{array}$ \\
\hline USP - Universidade de São Paulo & $\mathbf{X}$ & $\mathbf{X}$ & $\mathbf{X}$ & $\mathbf{X}$ & $\mathrm{X}$ \\
\hline UNESP - Universidade Estadual Paulista & - & - & $\mathbf{X}$ & $\mathrm{X}$ & $\mathrm{X}$ \\
\hline UNICAMP - Universidade Estadual de & & & & & \\
\hline Campinas & - & $\mathbf{X}$ & $\mathbf{X}$ & $\mathbf{X}$ & $\mathbf{X}$ \\
\hline UFV - Universidade Federal de Viçosa & - & $\mathbf{X}$ & $\mathbf{X}$ & $\mathbf{X}$ & $\mathbf{X}$ \\
\hline UFG - Universidade Federal de Goiás & $\mathbf{X}$ & - & $\mathbf{X}$ & $\mathrm{X}$ & $\mathrm{X}$ \\
\hline UFC - Universidade Federal do Ceará & - & - & $\mathbf{X}$ & $\mathbf{X}$ & $\mathbf{X}$ \\
\hline IFGoiano - Instituto Federal Goiano & - & - & - & - & $\mathrm{X}$ \\
\hline UFLA - Universidade Federal de Lavras & $\mathbf{X}$ & - & $\mathbf{X}$ & - & $\mathrm{X}$ \\
\hline UFPa - Universidade Federal do Pará & - & - & - & $\mathbf{X}$ & $\mathrm{X}$ \\
\hline UEM - Universidade Estadual de & & & & & \\
\hline Maringá & - & $\mathbf{X}$ & $\mathbf{X}$ & $\mathbf{X}$ & $\mathbf{X}$ \\
\hline UFRJ - Universidade Federal do Rio de Janeiro & - & $\mathbf{X}$ & $\mathbf{X}$ & $\mathbf{X}$ & $\mathbf{X}$ \\
\hline Rio de Janeiro & - & - & $\mathbf{X}$ & - & $\mathbf{X}$ \\
\hline UCS - Universidade de Caxias do Sul & - & - & $\mathbf{X}$ & - & $\mathbf{X}$ \\
\hline UPF - Universidade de Passo Fundo & - & - & $\mathbf{X}$ & $\mathbf{X}$ & $\mathbf{X}$ \\
\hline $\begin{array}{l}\text { UFRGS - Universidade Federal do } \\
\text { Rio Grande do Sul }\end{array}$ & - & $\mathbf{X}$ & - & $\mathbf{X}$ & $\mathbf{X}$ \\
\hline FURG - Universidade Federal do Rio Grande & $\mathbf{X}$ & - & $\mathbf{X}$ & - & $\mathbf{X}$ \\
\hline UFSC - Universidade Federal de Santa Catarina & - & - & $\mathbf{X}$ & $\mathbf{X}$ & $\mathrm{X}$ \\
\hline UFS - Universidade Federal de Sergipe & - & - & - & - & $\mathrm{X}$ \\
\hline Instituto Mauá & - & $\mathbf{X}$ & $\mathbf{X}$ & $\mathbf{X}$ & $\mathbf{X}$ \\
\hline $\begin{array}{l}\text { FENVA - Faculdade de Engenharia de Varginha } \\
\text { PUC/PR - Pontifícia Universidade }\end{array}$ & - & - & - & - & - \\
\hline Católica do Paraná & - & - & - & - & - \\
\hline $\begin{array}{l}\text { UESB - Universidade Estadual do } \\
\text { Sudoeste da Bahia }\end{array}$ & - & - & - & - & - \\
\hline $\begin{array}{l}\text { UFPB - Universidade Federal da Paraíba } \\
\text { UNIFEB - Fundação Educacional de }\end{array}$ & - & - & - & - & - \\
\hline Barretos & - & - & - & - & - \\
\hline UNIMEP - Metodista de Piracicaba & - & - & - & - & - \\
\hline UNISINOS - Universidade do Vale do Rio dos Sinos & - & - & - & - & - \\
\hline
\end{tabular}

Note: The "X" indicates the existence, while "-" the absense of an association in the respective program. Source: The authors, based on information available on the websites of the analyzed programs

particularities in how fields of knowledge are constituted, in addition to their representativeness in the total program workload.

However, initial analysis is suggestive with respect to understanding that Brazil is not properly doing its homework based on global changes in food engineering education. The most important task will be the reduction of time spent inside classrooms. Some other aspects related to the economic, political, social, and environmental context stand out, giving a particular identity to the profile of the Brazilian school. Nevertheless, there is still a long way to go to integrate and standardize learning experiences for all students of distinct food engineering programs.

As homework, the initial analysis suggests an early opportunity to rethink certain issues, such as workload, transversal content, and teaching tools required to improve the alignment of Brazil with the vanguard movement facing food engineering education.

As well as improving the suggested methodology, a second stage of the study was structured, consisting of interviews with program coordinators, in order to search for a comparative analysis of the content; and even a comparison between the American, European, and Brazilian food engineering schools.

\section{Acknowledgements}

Our special thanks to the CORS (Center for Organizational Studies) and the GEPEC (Group of Studies and Research on Strategy and Vertical Coordination) for providing a rich environment 
for the development of the present study. The authors are also grateful to Marcia G. Kasemodel, for her comments, suggestions, and technical assistance. Finally, the authors acknowledge the São Paulo Research Foundation (FAPESP) for the financial support (CEPID FoRC 13/079148 ), as well as the Brazilian National Council for Scientific and Technological Development (CNPq) for the Research fellowship of Paulo J.A. Sobral.

\section{References}

Abramovay, R. (1992). Paradigmas do capitalismo agrário em questão-hucitec. Anpocs/Edunicamp-São Paulo-Campinas.

Aguilera, J. M. (2006). Seligman lecture 2005 - food product engineering: building the right structures. Journal of the Science of Food and Agriculture, 86(8), 1147-1155. doi:10.1002/jsfa.2468

Alves, G. R., Restivo, M. T., \& da Silva, J. B. (2015). Special issue on engineering education: challenges for innovation. European Journal of Engineering Education, 40(5, SI), 451-458. doi:10.1080/03043797.2015. 1059409

Barbosa-Canovas, G. V. \& Ibarz, A. (2002). Unit operations in food engineering. CRC press.

Batalha, M., Marchesini, M., Costa, M., Bergamaschi, M., Rinaldi, R., \& Moura, T. (2005). Recursos humanos e agronegócio: a evolução do perfil profissional (J. Berman \& L. Ritchie, Eds.). São Paulo: Novos Talentos.

Berman, J. \& Ritchie, L. (2006). Competencies of undergraduate business students. Journal of Education for Business, 81 (4), 205-209. doi:10.3200/JOEB.81.4.205-209

Besterfield-Sacre, M., Cox, M. F., Borrego, M., Beddoes, K., \& Zhu, J. (2014). Changing engineering education: views of us faculty, chairs, and deans. Journal of Engineering Education, 103(2, SI), 193-219. doi:10. 1002/jee.20043

Borrego, M. \& Bernhard, J. (2011). The emergence of engineering education research as an internationally connected field of inquiry. Journal of Engineering Education,
100(1), 14-47. doi:10 . 1002 / j . 2168 9830 . 2011 . tb00003 .x. eprint: https : / / onlinelibrary.wiley.com/doi/pdf/10.1002/j. 2168-9830.2011.tb00003.x

Bulmer-Thomas, V. (2003). The economic history of latin america since independence. Cambridge University Press.

Costa, R., Mozina, S. S., \& Pittia, P. (2014). The regulation of food science and technology professions in europe. International Journal of Food Studies, 3(1). doi:10.7455/ijfs/ 3.1.2014.a10

Dillon, J., Rickinson, M., Teamey, K., Morris, M., Choi, M. Y., Sanders, D., \& Benefield, P. (2006). The value of outdoor learning: evidence from research in the uk and elsewhere. School Science Review, 87(320), 107-111.

Eccles, J. S. \& Barber, B. L. (1999). Student council, volunteering, basketball, or marching band: what kind of extracurricular involvement matters? Journal of Adolescent Research, 14(1), 10-43. doi:10.1177/ 0743558499141003

Flynn, K., Bejarano, B. R., Wahnstrom, E., Echim, C., \& Quintas, M. A. C. (2013). Profile of currently employed european food scientists and technologists: education, experience and skills. International Journal of Food Studies, 2(2).

Gair, N. P. (1997). Outdoor education: theory and practice. Weidenfeld and Nicolson.

Guia do Estudante. (2016). Entenda como é feita a avaliação dos cursos do guia do estudante. Retrieved from http://guiadoestudante . abril.com.br/universidades/entenda-comoe-feita-a-avaliacao-de-cursos-do-guia-doestudante/

Karel, M. (1997). The history and future of food engineering. Food Engineering 2000, 3-19.

Kasemodel, M.-G. C., Makishi, F., Souza, R. C., \& Silva, V.-L. (2016). Following the trail of crumbs: a bibliometric study on consumer behavior in the food science and technology field. International Journal of Food Studies, 5(1).

Knight, J. (2004). Internationalization remodeled: definition, approaches, and rationales. Journal of Studies in International 
Education, 8(1), 5-31. doi:10 . $1177 /$ 1028315303260832

Kostaropoulos, A. (2012). Food engineering within sciences of food. International Journal of Food Studies, 1(2).

Loncin, M. (2012). Food engineering: principals and selected applications. Food science and technology. Elsevier Science. Retrieved from https: / / books.google.pt/books?id= YqH1d5FaC20C

Lucena, J., Downey, G., Jesiek, B., \& Elber, S. (2008). Competencies beyond countries: the re-organization of engineering education in the united states, europe, and latin america. Journal of Engineering Education, 97(4), 433-447. doi:10.1002/j.21689830.2008.tb00991.x

MEC. (2016). Cadastro e-MEC de instituições e cursos de educação superior: Sistema eMec. Ministério da Educação. Retrieved from http://emec.mec.gov.br

Melsa, J. L., Rajala, S. A., \& Mohsen, J. P. (2009). Creating a culture for scholarly and systematic innovation in engineering education. Journal of Engineering Education, 98(3), 209-209.

Paisley, K., Furman, N., Sibthorp, J., \& Gookin, J. (2008). Student learning in outdoor education: a case study from the national outdoor leadership school. Journal of Experiential Education, 30(3), 201-222. doi:10. 1177 / 105382590703000302. eprint: https : //doi.org/10.1177/105382590703000302

Roos, Y. H., Fryer, P. J., Knorr, D., Schuchmann, H. P., Schroen, K., Schutyser, M. A. I., ... Windhab, E. J. (2016). Food engineering at multiple scales: case studies, challenges and the future-a european perspective. Food Engineering Reviews, 8(2), 91115. doi:10.1007/s12393-015-9125-Z

Rychen, D. S. \& Salganik, L. H. (2003). Key competencies for a successful life and wellfunctioning society. Hogrefe Publishing.

Saguy, I. S. \& Cohen, E. (2016). Food engineering: attitudes and future outlook. Journal of Food Engineering, 178, 71-80. doi:10 . 1016/j.jfoodeng.2016.01.009

Saguy, I. S., Singh, R. P., Johnson, T., Fryer, P. J., \& Sastry, S. K. (2013). Challenges facing food engineering. Journal of Food
Engineering, 119(2), 332-342. doi:10.1016/ j.jfoodeng.2013.05.031

Silva, V. L., Sereno, A. M., \& do Amaral Sobral, P. J. (2018). Food industry and processing technology: on time to harmonize technology and social drivers. Food Engineering Reviews, 10(1), 1-13. doi:10.1007/s12393017-9164-8

Skidmore, T. E. (2009). Brazil: five centuries of change. New York, NY, USA: Oxford University Press.

Wood, D. F. (2003). Problem based learning. BMJ: British Medical Journal, 326(7384), 328-330. doi:10.1136/bmj . 326.7384.328. eprint: https: / / www . bmj . com / content / 326/7384/328.full.pdf 